\title{
Philosophy in Materializing Stone Monuments: Issues with Poumai Naga Megaliths in Manipur (India)
}

\author{
Maringmei Philip ${ }^{(1)}$ and Mayanglambam $\mathrm{ManiBabu}^{(2)}$ \\ ${ }^{(1)}$ Research Scholar, ${ }^{(2)}$ Professor, \\ Department of Anthropology, Manipur University, Canchipur, Imphal-795 003 (INDIA)
}

\begin{abstract}
Megalithic monuments are not the simple resultant anthropogenic structure but are the immovable media that embody deeper set of meanings relating to how the material themselves are perceived and understood to the builders within a social system. Hence, their significant manipulation as external symbolic storage is well connected with the peoples' cultural mundane deportment. And the collective and complex cultural identities of the builders may be perceived through cultural channels intentional treatment of these monuments that allow us for a better identification of different layers of social identity. The present paper is an attempt to explore such domains related to the living megalithic tradition among the Poumai Naga tribes who inhabit the Oinam village in the Senapati District, Manipur (India). It is seen that the Poumai traditional way of erecting large stone monuments is related with their materialization as external symbolic storage, manifesting one's wealth and attainment of social status, and thus acts a material means to communicate and manipulate ideas to the viewers.
\end{abstract}

Keywords - Materiality, Megalithic, Poumai Naga

\section{INTRODUCTION}

In order to see the intrinsic relations that material culture (such as, stone artifacts, pottery, large stone monuments, etc) have in the larger respective social network, one needs to emphasize materiality in many facets. The concept of materiality in archaeology is of recent development [1]. It is asserted that materiality is 'to emphasize the physicality of the material world' [2], and to understand of how particular pieces of stone are given form and meaning within specific social and historical contexts [3]. In terms of the conceptual meaning, materiality and material culture are not synonymous though the two 'share some similarities, but also some important differences' [4]. The term materiality 'is just not a substitution for material culture, but embraces a greater variety of things and substances' and its 'active role ... in the social process seems not to be about their initiating and modifying agency, but rather about their presumed symbolic function'[5]. Its main characteristic is its physicality, and 'to study material culture is to consider the implications of the materiality of form for the cultural process' [6]. Conceptually expansion of materiality, hence include a wider perspective of how objects are integrated in the social realm [7].The present paper attempts to enumerate the nature on how megalithic monuments as an important asset of material culture are being materialized within peoples' socio-cultural milieu. And the population under study,the Poumai is one of the Naga tribes who inhabit in the Oinam hill village in the Senapati District, Manipur among whom erection of megalithic monuments is a living tradition. And they constitute one of the largest Naga tribe followed by Mao and Marams of the State. The word Poumai literally means 'people of Pou' (pou- the progenitor, mai- the descendants). The people of the village called themselves as Oinamee (the man of Oinam). The village is divided into five segments (on the basis of clusters of clan) or khels as they are called - such as, Laneme, Singneme, Thoulaneme, Daeme and Khaneme. A good number of exogamous paticlans are found in each khel. And, the exogamous character of clan even extended to the level of khels also. Thus khels are also exogamous in nature, and marriage cannot takes place among the clan groups scattered within a khel. Clans found within each khel are given in the following table.

Table-1: Khels at the Oinam Hill village with their corresponding clans

\begin{tabular}{|l|l|}
\hline \multicolumn{1}{|c|}{ Khels } & \multicolumn{1}{c|}{ Partri-clans within the khel } \\
\hline Laneme & Polaneme, Reikame, Varayneme, Teilaoneme and Houneme \\
\hline Singneme & Sangneme, pesuineme andChaoneme \\
\hline Thoulaneme & Rongkame, Phutaoneme and Raoneme \\
\hline Daeme & Khopuneme, Paokame, Paoneme and Raemanneme \\
\hline Khaneme & (Uninhabited village area) \\
\hline
\end{tabular}


The land of Oinamee is bestowed with rich natural resources of vegetation, wild fauna and land. The Oinam hilly tract as well as the surrounding areas is characterized by outcrops of small and large hills that dot all over the landscape in the entire region. Besides many traces of indigenous traditions and technologies of archaeological significances, manufacture of cloth from bark fibre and production of both plain and cordmarked handmade pottery are the two important traits still in vogue in the village.

\section{POUMAI WAY OF MATERIALIZING MONUMENTS}

It is still a regular practice to the people to erect large stone monuments near their habitat and this very tradition is a part of their social life, connected very much with the attainment of social status of a person who initiates to erect such large monuments. In one's lifetime a male individual can initiate to erect such stone monoliths whenever he is sufficiently affluent to do so, that is, if he could bear the huge expenditure to be incurred during the erecting procedure. Erection of a stone monolith is done duly with organizing a feast by a donor and thus giving feast of merit is a social reciprocal system manifesting generosity, compassion and concern to the fellow community. Performance of feasts of merit is rather expensive in terms of commodities spent like paddy, buffaloes, pigs and rice beer. A huge monolith is dragged from a distance, by the young men partaking the ceremony, and it is erected at a convenient place to commemorate the holding of the feast. The stone pulling is an occasion for great festivity in the village. The host arranges for drums of rice beer and mountains of beef and pork, which are served to all those who join the ceremony. The wife of the donor plays an important part and so only a married man can host a feast of merit.There are series of feasts, each one costlier than the preceding one. Every feast entitles the host to social distinction and increases progressively his standing and position in the community. It also entitles him to wear special dress and ornaments and decorate his house in a particular manner, marking him out from others in the village. The erection of monuments and giving of feasts of merit by a donor is basically reciprocal, in the sense that these two are very much the requirements for a person to have a social status in the society. For such a performance, a number of requisite procedures are to be observed before an erection of a monument. The way the Oinamee erects stone is worth concerned with the indigenous system of materializing stone into monument which owes its relations with their understanding of form and meaning within specific social contexts. In order to materialize stone monuments as megaliths, the large stones are to erect categorically with the performance of a feast (feast of merit) by a man to his fellow people. Through feast of merit a wealthy man transmits his own fertility, proof of which is his wealth, to the members of the community by offering meat, rice and rice-beer in course of erecting a stone monument, and receiving in turn merit and social prestige. Obviously, such stone monuments are the material manifestations of wealth of a person who, by virtue of his of expensive gratification, earn for himself respect and reputation of being generous and resourceful. Performing feasts of merit, though slightly different in the way and procedure from one community to community, form the Naga way of ethics and social life. These successful performers of the feasts of merit automatically acquire the social sanction to wear special cloths with distinctive embroideries on them, and to add house the horns of the animals killed on their dwellings. The donor of the feast of merit alone could wear a special kind of home-spun cloth, the finest one, known as Phaiju. A man is free to carry out feast of merit and for this he is required to get registered himself first to the village authority (Chame) with a nominal fee (as reported by the village elders, a sum of six rupees was the fee charged during mid-seventies). In the month of August (Raotheiho-Louho), he is supposed to offer one pig with a little local wine. Once a donor get registered himself to the village authority (chame) for the performance of a feast of merit, he not only restrained himself to have sexual relationship with his wife but also not to eat rice cooked, or drinks rice beer prepared/ served by her. At the same time, he should not take bathe and restrained to consume bitter and sour foods also[8].

Mental as well as corporeal preparation for a feast of merit begins well ahead the ceremony. Meat and rice beer form the main components for series during the ceremony. And the animal, such as, buffaloes that are to put to use for flesh are well tended beforehand to make them physically fit, such as they should be physically fit in all respect without any sign of blemish and deformity, all the teeth of the animal should be intact without any missing, any wear and tear on its horn, any patches of white colour on the fur, any whirls of their hair on the neck area and behind the ears. As the time for the feast is nearing, preparation of rice beer begins. This was mainly done by women, close friends and relatives of the performer. The clan members and relatives of the 
donor would collect firewood from the nearby forest that would be required to brew wine and for cooking rice and meat. Rice beer is generally made from a variety of local rice called datho. This variety of rice is sticky in nature and grown specially for making rice beer and not for general consumption. To make rice beer, the paddy grain (datho) is first soaked into water for one night. Then liquid is drained out and make it dry. The soaked and dried datho is then pounded. The flour of datho is then mixed with it the kha (the yeast), which is also made out of rice.For making $k h a$, paddy grain is soaked for about two days and then put these into a bamboo container after covering with banana leaves in order to germinate. Afterward the germinated paddy is dried. These dried, sprouted grains are ground into powder, which is used as yeast to make rice beer. The powdered yeast after mixing with the flour of datho in a given proportion is kept in an earthen vessel for about three days, after which it can be consumed.

Selection of large stone to be erected is a matter of choice by the donor though omen and dream. The village priest (lopi) and the donor would look for the stone in the forest-land of the clan/khel under which the later belonged. If any stone have come across by the person to his choice, the priest shall perform a ritual beginning with wine oblation to the stone, pouring a little of wine over a piece of plantain-leaf near the stone boulder. Afterwards, a piece of ginger should be kept just beside the stone. The same night the man will see for a good or bad omen in his dream. In case he had a bad dream then it is taken that the stone that they had chosen is not suitable for an erection, and shall try for another stone.Pulling of stone is usually done during dry season, preferably by the end of November. It was a tradition where, the priest and the donor should always be together till the end of the ritual performed. Pulling of the stone is done by the youths, and just before its initial displacement from the resource outgrowth, one buffalo and one pig are to be sacrificed. The blood of the pig is to be stained over the stone. It is done on a general belief that stones also have life, and if they put bloodstain over it the stone is perceived to be a dead, and no harm will occur to them. As and when the stone is pulled out of the exploitation site (talladobe), any item is to be kept at the place as a replacement of the earlier one. And also a live chicken is to hang on a branch of the khatree at the same place.The large stone is transported after being placed on a long wooden sledge being tied with a special kind of creepers. Pulling the same is first initiated by the village priest along with the village youths, and afterward with the donor. It may take several days in transporting the stone to the site where the monolith is suppose to erect. After being transported, the stone is placed in a particular place locally known as tasungbe. Erection of monoliths is usually done on the fifth day of the month of December (Louho). After the stone is erected - relatives, friends and youths who took part in dragging the stone, joined in the grand feasts offered by the donor and his family.

\section{THE POUMAI PHILOSOPHY IN MATERIALIZING MONUMENTS}

The Poumai system of exploiting large stones towards materializing them into monuments envisages a categorical manifestation of inner meaning bestowed to these tangible silent materials.There exists an attachment of the stone object with the very person who initiates to erect it, and hence the individual's social identification is dependant with the categorical erection of the stone which shows how that person interacts with material culture and with other fellow subjects through grand feast (the feast of merit). Naturally, there is reciprocity between actors (the donors) and the monuments in configuring the actors understand themselves in the society in terms of their identity and status. Status, as such, is the relative social position of an individual, and is contingent on the significance and meaning that are accumulated in social life[9]. A status thus achieved by a Naga male through 'the feasts of merit were separate from the status of being chief or a member of a noble clan' [10]. And also this schema does not reflect to be the hallmark of a stratified society as stipulated by many in as much as in public architecture [11].

The Poumai system of materializing large and naturally-occurred stone objects can be perceived with a triadic loop - contravene of wealth, giving of a feast and achievement of social status. It is a fact that a megalithic monument itself manifest as one of the strongest index of wealth, where wealthy persons in order to achieve a status in the society organized a feast lavishly to the people and erect a large stone monument as a symbol of his wealth and power. And, wealth as items used in 'display, ritual, and exchange' [12] can and often does reflect status. However, wealth, status, and class are related terms but are not interchangeable [13]. In fact, monumentality constitutes conspicuous consumption that objectifies the social power used to mobilize human labour. The symbolic meaning of megalithic monuments, in spirit, lies at the community level, as these manifest 
material signatures of an individual's status at the expense of the fellow members' cognizance. Hence, such monuments are the signified 'prestige items' to the community to gauge status of concerned individuals, and not simply chunks of rock, strands of material culture or contexts of a social landscape. By way of channelizing through the material world, The Naga ways of megalithic materiality (such as, activities) and monumentality (that is, the identities) become part of peoples' placid social system characterized by the 'repetition of the practices'. With such common practices, the society shared a 'community identity' through a 'shared system'. It emphasizes how these monuments are built on a 'shared knowledge system' providing mutually intelligible ideas of status and difference. It is perceived that megalithism has become an articulated attribute of Poumai Naga identity conventionalized through peoples' collective legacy and ideas of inheritance.

Another important aspect in the materialization of stone monuments lies with the mode of their placement within a categorical spatial bound of the village. Within the theoretical paradigm of space syntax analysis, a general distributional pattern of megalithic monuments can be detected. The space syntax analysis (SSA) refers to spaces that 'can be broken down into components, analysed as networks of choices, and then represented as maps and graphs that describe the relative connectivity and integration of those spaces'. And with this we can outline 'a cognitive approach to the environment (landscape) where megalithic monuments are located' and aims 'to understand and explain certain aspects of human behaviour and their relation to the environment which the people have built and dwelled in' [14]. Some aspects that we could observe include -

i) The spatial distributions of monuments, irrespective of their typological categories within the village boundary, are related with the spaces where there is a maximum accessibility of human movement. It is a regular phenomenon that menhirs, alignments and stone seats are located either by the sides of the intervillage lanes or at the core areas (central places) of the village. Many of the stone seats are also seen by the side of the village road leading to the forest or terrace fields. Thus, a spatial logic of movement of humans can be identified, which according to theorems of space syntax delineated that more integrated spaces are associated with higher densities of movement. Such a relationship within the SSA can be used 'to predict the flows and helps to formulate alternative scenarios to fit development sites into their surroundings' [15].

ii)While selecting space for erecting monument, obviously one is to erect within the boundary of the land (i.e. the khel) where the donor (who erect monument) belongs. The management of space by a donor is, thus attested with his belongingness to a spatial boundary by virtue of his khel affiliation. The mental space is thus related with human behavior on management of space which manifests the concept the spatiality within the settled area[16].

\section{SUMMARY AND OBSERVATIONS}

The basic proposition of the present discussion is to highlight how an indigenous people could materialize naturally-occurred object, the stones, by way of erecting them through a socially-sanctioned norms thereby giving meaning to them as well as to the agent, the builder.The fact that among the population under study physicality of large stone boulders that are being materialized duly with symbolic meaning owes to an indigenous system of exposing one's ability to throw wealth by way of giving feast to the fellow members at the cost of gaining a position in the society. Thus, the physicality of artifact in the form of erected monument, for instance, is hence materialized, projecting meaning and message to the viewers, though not living but as an organic. The Oinam system of materializing stone blocks into monuments is none other than the transformation of ideas and values, and propagation of meaning of a system into a physical reality as a symbolic object sharing and participating with the viewers. The Oinam example reveals that the means and forms of materialization are related with the investment of resources and transportation of wealth into prestige, power and status. Here, competition for prestige and power takes the form of feasting, the feast of merit. And thus the three components - wealth, feasting and status - are the complementary and reciprocal themselves. A wealthy person obviously try to achieve a status in the society, organized a feast lavishly to the people at the cost of pulling and erecting a large stone monument, a symbol of his wealth and power.Thus materialization of stones into monuments can be seen as an outcome of throwing wealth via communal feasting as a substantial social strategy. And the Poumai philosophy of monumentality is centered round the status symbol not only with the megaliths erected but also with the ethnic insignia of special cloth, decorated spear, decorated house with a special mark, animal horns, and so on. Thus, the subjective meaning impose on megaliths bears a normative debut on what they believe and not just on what is objectively true. 
On the other hand, the present data provides a new arena to the role and effect of megaliths in the setting of the village landscape. The location of megalithic in the village is not merely a setting or background, it is indeed a context in its etymological meaning, and it is the fabric of their formation. Moreover, a spatial cognition to the erection and placement of monuments based on a correlative arrangement between environment and human movement exist where the spatial distributions of monuments are related with the spaces where there is a maximum accessibility of human movement. The management of space is also attested with his belongingness to a spatial boundary by virtue of his khel affiliation. The mental space is thus related with human behavior on management of space which manifests the concept the materiality of monuments[17]. This however,has ethnographic analogical significances at least in detecting deserted ancient habitation sites on the basis of the spatial characters of stone megaliths as perimetric features which demarcate the village boundaries.

\section{REFERENCES}

[1] DeMarrais, E; C. Gosden and C. Renfrew (eds.) Rethinking Materiality: the Engagement of Mind with the Material World. Oxford: McDonald Institute for Archaeological Research. 2004.

Tilley C. The Materiality of Stone: Explorations in Landscape Archaeology. Oxford: Berg. 2004.

Fahlander, F. and T. Oestigaard 'Introduction: Material Culture and Post- Disciplinary Sciences'. In, Fahlander, F. and T. Oestigaard (eds.) Material Culture and other Things- Post-disciplinary studies in the $21^{\text {st }}$ Century. Pp. 1-18. Gotarc Series C, No. 61.Gothenburg. 2004.

Miller, D. (ed.). Materiality. Durham, N.C.: Duke University Press. 2005.

Meskell, L. 'Objects in the Mirror appear closer than they are'. In, Miller, D. (ed.) Materiality. 2005, Pp. 51-71. London: Duke University Press.

Meskell, L. (Ed.) Archaeologies of Materiality, Malden: Blackwell. 2005.

Tilley, C. Introduction. Handbook of Material Culture Studies. London: Sage Publications. . 2006.

Ingold, T. Materials against Materiality. Archaeological Dialogues 14(1): 2007, 1-16.

[2] Boivin N. Material Cultures, Material Minds: The Impact of Things on Human Thought, Society and Evolution. Cambridge: Cambridge University Press. 2008.

[3] Tilley C. The Materiality of Stone: Explorations in Landscape Archaeology. Oxford: Berg. 2004.

[4][5] Fahlander, F. and T. Oestigaard 'The Materiality of Death Bodies, burials, beliefs'. In, Fahlander, F. and T. Oestigaard (ed) The Materiality of Death Bodies, burials, beliefs. 2008, Pp. 1-16. BAR International Series 1768. Oxford: Archaeo press.

[6] Miller, D. 'Artefacts and the Meaning of Things'. In, Ingold, T. (ed) Companion Encyclopedia of Anthropology. 1994, Pp. 396-419. London: Routledge.

[7] Fahlander, F. and T. Oestigaard 'The Materiality of Death Bodies, burials, beliefs'. In, Fahlander, F. and T. Oestigaard (eds.) The Materiality of Death Bodies, burials, beliefs. 2008, Pp. 1-16. BAR International Series 1768. Oxford: Archaeo press.

[8][9] ManiBabu, M. 'Making Sense of Stones: Wealth, Status and Indigenous Management Strategy' In, Jose, K. and G.K. Bera (eds.) Indigenous Resource Management in North East India.2014, Pp. 192-217. New Delhi: Osmons Publications.

[10] West, A.C. Nineteenth Century Naga Material Culture. Newsletter (Museum Ethnographers Group) 18: 1985, 21-34.

[11] Childe, V. G. The Urban Revolution. Town Planning Review. 21: 1950, Pp. 3-17.

Sanders, W., and B. Price Mesoamerica: The Evolution of a Civilization. New York: Random House. 1968.

Drucker, P. On the Nature of the Olmec Polity. In, Bensen, E. (ed) The Olmec and Their Neighbors. 1981, Pp. 29-47. Washington, D. C.: Dumbarton Oaks.

[12] LeCount, L. J. Polychrome Pottery and Political Strategies in Late and Terminal Classic Lowland Maya Society. Latin American Antiquity 10: 1999, 239-258.

[13] Babic, S. 'Status, Identity and Archaeology'. In, Diaz-Andreu, M., S. Lucy, S. Babic, and D. N. Edwards (eds.) The Archaeology of Identity: Approaches to Gender, Age, Status, Ethnicity, and Religion. 2005, Pp. 67-85. New York: Routledge.

[14] Dimitriadis, G. Looking for Metals: Megalithic Monuments between reality and mythology. In, Kostov, R. I.; B. Gaydarska, M. Gurova (eds.).Geoarchaeology and Archaeomineralogy - Proceedings of the 
Philosophy in Materializing Stone Monuments: Issues with Poumai Naga Megaliths in Manipur ..

International Conference, 29-30 October 2008. Sofia, Publishing House "St. Ivan Rilski”, Sofia, 2008, Pp. 205-210.

[15] Peponis, J. Interacting Questions and Descriptions. Proceedings of 3rd International Space Syntax Symposium Atlanta 2001. 2001, Pp. 13-26. Atlanta, Georgia.

[16][17]ManiBabu, M. 'Making Sense of Stones: Wealth, Status and Indigenous Management Strategy' In, Jose, K. and G.K. Bera (eds.) Indigenous Resource Management in North East India.2014, Pp. 192-217. New Delhi: Osmons Publications. 